\title{
ENCODED STRUCTURES: \\ CONSTRAINT-BASED DESIGN OF MODULAR BEAMS \\ CODIERTE STRUKTUREN: \\ CONSTRAINT-BASIERTE KONSTRUKTION MODULARER ELEMENTE
}

フ ADAM ORLINSKI, CLEMENS PREISINGER, MORITZ HEIMRATH // German translation: Christa Wendl

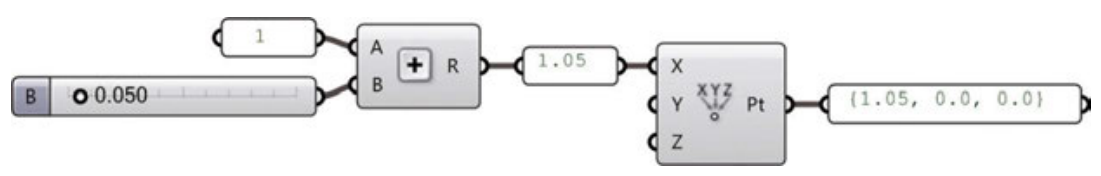

Fig. 1 | Abb. 1:

Simple definition: generating a point with Cartesian coordinates (image source: Karamba3d).

\section{WAYS OF WORKING:}

Parametric modelling and advances in computeraided design have prompted a modified understanding of what geometry creation can be. 'Making geometry' has expanded from a drawing- or modeling-based approach towards a generative one (Fig. 1). Access to algorithmic modelling platforms and visual programming languages such as Grasshopper $3 D$ has made it possible for parametric workflows to assist in organizing formal complexities in a much more interconnected way. Geometric compositions no longer accumulate due to static, step-by-step operations, but rather interlink through a record of algorithms, whereby shapes emerge through programmed rules and flexible parameters.

\section{ORGANIZING QUANTITIES:}

One consequential effect of these workflows is an updated mastery of dealing with large quantities of elements at the same time. The difference between 5 , 50 or 500 times often reflects the change of a single parameter, changing the relationship between time, effort and quantity. Instructions for building shapes and forms have directly replaced building shapes and forms, and the focus has shifted towards assembling the right algorithms, rules and parameters to create geometric ensembles.

\begin{abstract}
ARBEITSWEISEN:
Parametrisches Modeling und Fortschritte im Bereich der computergestützten Konstruktion haben zu einem veränderten Verständnis der Geometrieerstellung geführt. Das ,Erstellen von Geometrie' hat sich von einem zeichnungsoder modeling-basierten Ansatz hin zu einem generativen erweitert (Abb. 1). Algorithmische Modeling-Plattformen und visuelle Programmiersprachen wie Grasshopper $3 D$ haben es möglich gemacht, dass parametrische Workflows dabei helfen können, formale Komplexität mittels Vernetzung zu organisieren. Geometrische Kompositionen bilden sich nicht mehr infolge statischer Schritt-für-Schritt-Operationen heraus, sondern sind durch Algorithmen miteinander verbunden, wobei die Formen basierend auf programmierten Regeln und flexiblen Parametern entstehen.
\end{abstract}

\section{MENGEN ORGANISIEREN:}

Ein Folgeeffekt dieser Workflows ist die verbesserte Möglichkeit, große Mengen von Elementen gleichzeitig zu erzeugen. Der Unterschied zwischen 5, 50 oder 500 Mal spiegelt oft nur die Änderung eines einzigen Parameters wider, was das Verhältnis zwischen Zeit, Aufwand und Menge verändert. Das Bauen von Formen wurde auf direkte Weise durch Instruktionen zum Bauen von Formen ersetzt, und der Fokus hat sich auf die Erstellung der richtigen Algorithmen, Regeln und Parameter zur Erzeugung geometrischer Ensembles verlagert. 


\section{TOOL CLUSTERS \& COMBINATIONS:}

Parametric modelling is characterized by connecting various modules to chains of actions. Modules in use serve a specific task (small or big) in the design process, and often times stem from different disciplines with differentiated purposes. They perform within the same digital vocabulary - text/string, number/ float, point, vector, plane, Boolean, mesh, NURBS curves and surfaces, etc. - which allows them to exchange data and communicate in the same model environment. By connecting multiple modules to clusters, it is possible to bond their functionalities and blend tools into custom-made instruments.

\section{FOR EXAMPLE:}

Parametric geometry can be translated into a structural model that is evaluated for stiffness and deflection (Fig. 2). Changes in input parameters result in updates of the geometry (element count, distances, etc.), which then leads to a differentiated structural calculation result. The numeric calculation outcome can be furthermore connected to a genetic algorithm that links back to the initial input parameters. It iteratively runs through a large number of value changes, while remembering the resulting outcome. The effect is a recursive feedback loop that tracks parameter sets aimed towards a minimal structural deflection optimum.

\section{TOOL-CLUSTER \& KOMBINATIONEN:}

Das parametrische Modeling zeichnet sich durch die Verknüpfung verschiedener Module zu Handlungsketten aus. Die verwendeten Module dienen einer bestimmten (kleinen oder großen) Aufgabe im Konstruktionsprozess und stammen oft aus unterschiedlichen Disziplinen mit differenzierten Zwecken. Sie basieren auf dem gleichen digitalen Vokabular - Text/String, Zabl/Float, Punkt, Vektor, Ebene, boolscher Wert, Polygonnetz, NURBS Kurve und Freiformfläche, etc. -, wodurch sie Daten austauschen und in der gleichen Modellumgebung kommunizieren können. Durch die Verbindung mehrerer Module zu Clustern ist es möglich, deren Funktionalitäten zusammenzuführen und Tools zu maßgeschneiderten Instrumenten zu verschmelzen.

\section{BEISPIEL:}

Eine parametrische Geometrie kann in ein Strukturmodell übersetzt werden, dessen Steifigkeit und Durchbiegung ausgewertet werden (Abb. 2). Änderungen der Eingabeparameter führen zu Aktualisierungen der Geometrie (Elementanzahl, Abstände etc.), die dann zu einem differenzierten Strukturberechnungsergebnis führen. Das numerische Berechnungsergebnis kann darüberhinaus mit einem genetischen Algorithmus verknüpft werden, der auf die anfänglichen Eingabeparameter zurückgreift. Dieser durchläuft iterativ eine große Anzahl von Wertänderungen und merkt sich dabei das daraus resultierende Ergebnis. Der Effekt ist eine rekursive Rückkopplungsschleife, die Parametersätze mit minimaler statischer Durchbiegung sucht.

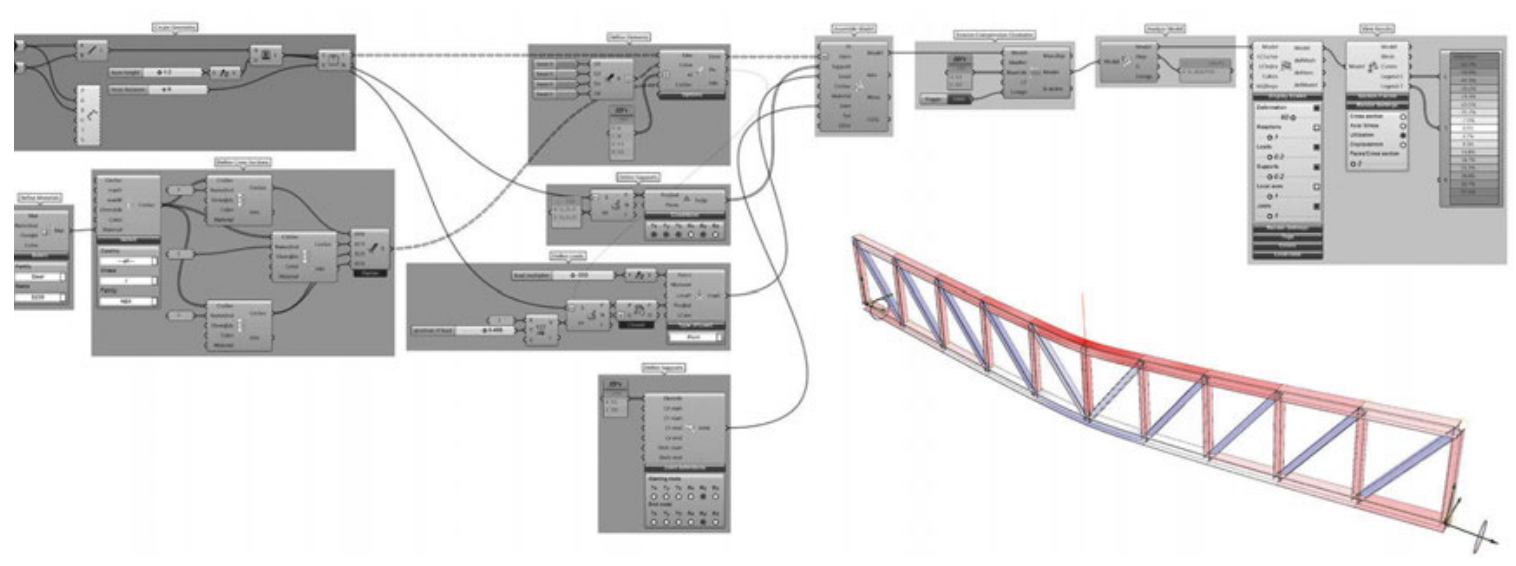

$\Delta$ Fig. 2 | Abb. 2:

Karamba3d - parametric definition (left) and calculated truss model (right bottom). The model automatically adapts to changing input parameters (image source: Karamba3d). 


\section{FORMATIONS FOLLOW ORCHESTRATION:}

Various strategies for managing geometric complexities, as well as add-on tools for analysis, computation and simulation, have emerged through distinct contributions to parametric modelling platforms. Building blocks that solve simple mathematic equations, or components that contain entire 'solvers' (for example, for structural calculation), have allowed geometry to be shaped according to precise information sequences from various fields. Geometry has taken steps towards embodying combined principles across multiple technologies and from multiple sources.

\section{ANIMATED, SIMULATED \& SCRIPTED: When updating parameters within an algorithmic framework, structures turn into flexible entities that adapt to changing circumstances. In architecture and especially in structural engineering, geometry is often seen as rigid or static. By displaying the ability to self-organize and to adapt to change, geometries can be animated, making them more malleable, plastic and dynamic in the process. Simulation tools such as Karamba3d or Kangaroo compute complex physical models with a multitude of parts, where- by each part embodies specific physical or material properties. While 'running' a solver for those mod- els, encoded properties combine and merge in a sim- ulated collective behavior of combined complexity.}

\section{GENETIC ALGORITHM:}

The White Noise pavilion was assembled from modular beam elements that were rigidly layered in longitudinal directions, while being randomly rotated in cross directions (Fig. 3). By addressing all the beam rotation parameters simultaneously, a genetic algorithm filtered hundreds of different arrangements for structural performance within specified design boundaries. After 5,000 generations, the evolutionary process tracked the configuration with the minimum deformation number and therefore the maximum structural stiffness. This methodology shapes a 'structural fitness' into the randomness of the project's body (Fig. 4).

\section{MAPPING FORCES TO FORM:}

Horizontal grids are interlaced through an algorithm that places one diagonal in each iteration (Fig. 5).

\section{FORMATIONEN FOLGEN DER ORCHESTRIERUNG:}

Infolge unterschiedlicher Beiträge zu parametrischen Modeling-Plattformen sind verschiedene Strategien zur Handhabung geometrischer Komplexität sowie Zusatztools für Analyse, Berechnung und Simulation entstanden. Bausteine, die einfache mathematische Gleichungen lösen, oder Komponenten, die ganze ,Solver ' (z. B. für Strukturberechnungen) enthalten, haben es ermöglicht, Geometrie nach präzisen Informationsfolgen aus unterschiedlichen Bereichen zu gestalten. Die Geometrie nähert sich einer Verkörperung kombinierter Prinzipien mehrerer Technologien und aus mehreren Quellen an.

\section{ANIMIERT, SIMULIERT \& GESKRIPTET:}

Durch das Aktualisieren von Parametern innerhalb eines algorithmischen Rahmens werden Strukturen zu flexiblen Gebilden, die sich an veränderte Gegebenheiten anpassen. In der Architektur und vor allem in der Tragwerksplanung gilt Geometrie oft als starr oder statisch. Durch die Fähigkeit, sich selbst zu organisieren und an Veränderungen anzupassen, werden Geometrien lebendig und damit formbar, plastisch und dynamisch. Simulationstools wie Karamba3d oder Kangaroo 2 berechnen komplexe physikalische Modelle mit einer Vielzahl von Teilen, wobei jedes Teil spezifische physikalische Charakteristika oder Materialeigenschaften verkörpert. Während ein Solver für diese Modelle, läuft', verbinden sich die kodierten Eigenschaften und verschmelzen in einem simulierten kollektiven Verhalten von kombinierter Komplexität.

\section{GENETISCHER ALGORITHMUS:}

Der White Noise Pavillon wurde aus modularen Stäben zusammengesetzt, die in Längsrichtung starr geschichtet und in Querrichtung zufällig gedreht wurden (Abb. 3). Durch die gleichzeitige Berücksichtigung aller Rotationsparameter der Stäbe filterte ein genetischer Algorithmus Hunderte von verschiedenen Anordnungen für die strukturelle Optimierung innerhalb der vorgegebenen Rahmenbedingungen heraus. Nach 5.000 Generationen hatte der evolutionäre Prozess die Konfiguration mit der minimalen Verformungszahl und damit der maximalen strukturellen Steifigkeit gefunden. Diese Methode verleiht der Zufälligkeit des Projektkörpers eine ,optimierte Strukturlogik' (Abb. 4).

\section{KRÄFTE AUF DIE FORM ABBILDEN:}

In der Studie „Stitching with Diagonals“ werden horizontale Trägerroste durch einen Algorithmus verwoben, der in jeder Iteration eine Diagonale platziert (Abb. 5). Die Mitte 
- Fig. 3 | Abb. 3:

Beam aggregation controlled through angle parameters, White Noise - soma architecture (image source: Bollinger+Grohmann).
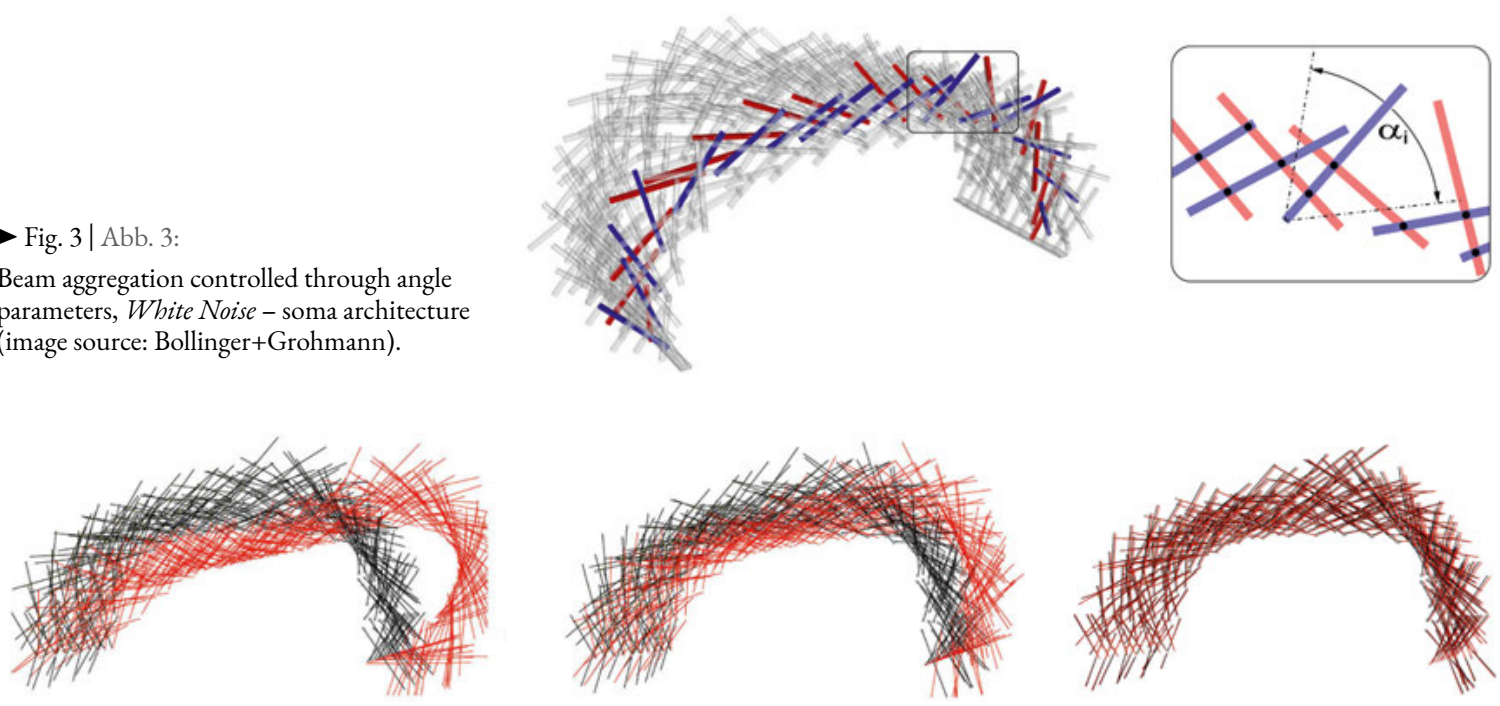

A Fig. 4 | Abb. 4 :

Evolutionary structural optimization using Karamba3d and Galapagos to find a beam aggregation (black lines) with a minimum deformation behavior (red lines), White Noise - soma architecture (image source: Bollinger+Grohmann).
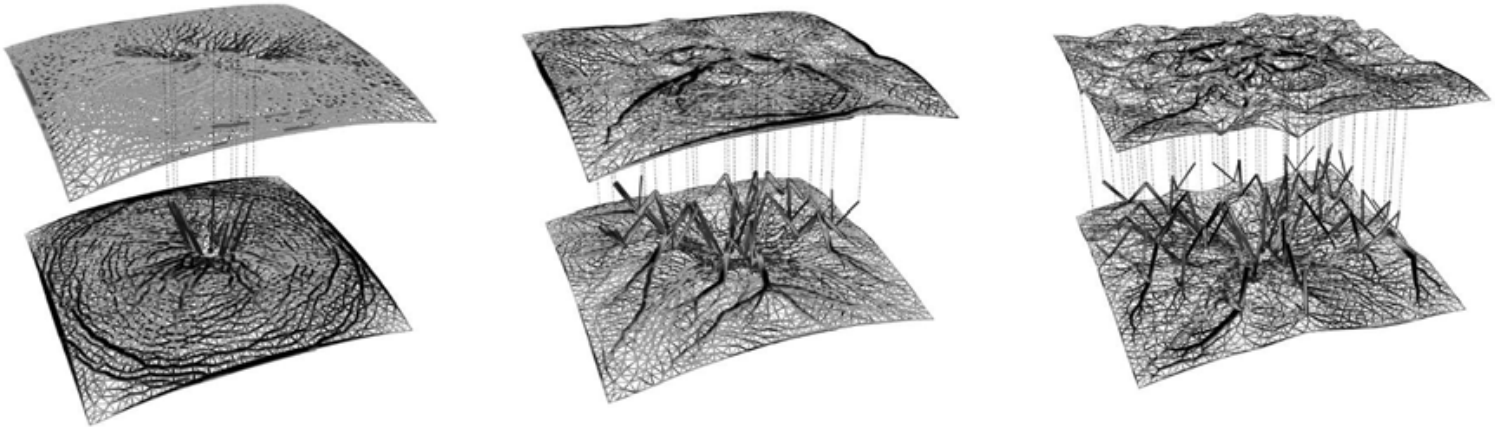

$\Delta$ Fig. 5 | Abb. 5:

Stitching with diagonals, iterations: $10.50 \& 100$ (image source: $n$. formations research project University of Applied Arts Vienna).

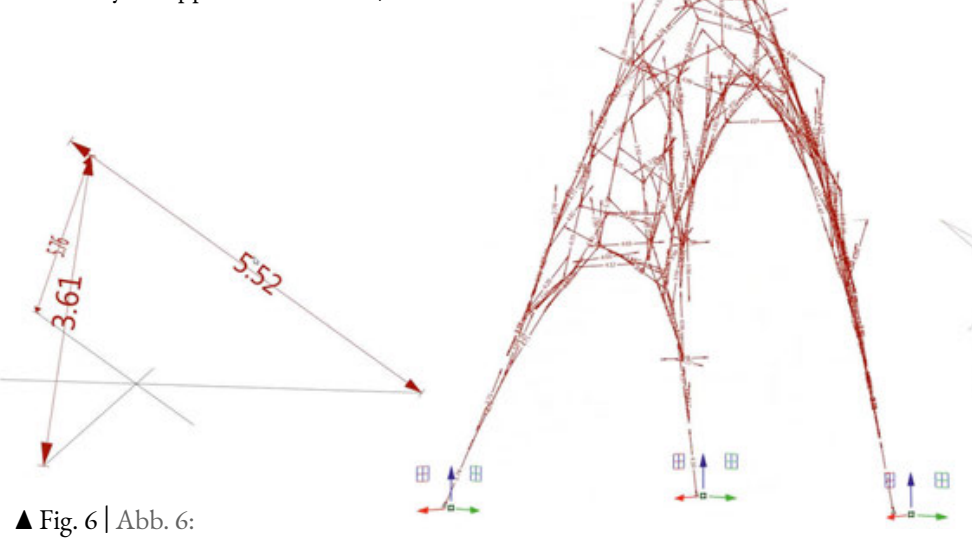

Left: simple reverse 'catenary' structure with three sliding beams,

Middle: complex reverse catenary structure with 200 sliding beams,

Right: sliding beams coupled with angle constraint, Kigumi Extended

(image source: Adam Orlinski / Conceptual Joining research project - University of Applied Arts Vienna). 
The center of the structure serves as a support cluster, where polylines 'grow' from the inside out. In each step, the algorithm adds one element in succession while continually orienting the newly created diagonal towards the spot with the lowest stiffness. When the edge of the grid is reached by all polyline agents, the algorithm stops, resulting in a unique, self-supporting spatial structural system.

\section{GOAL-BASED SOLVING:}

Kangaroo2 serves as a powerful engine for formfinding that can take various constraints and physical forces into account. A combinatory toolbox developed by Daniel Pirker, it performs goal-based solving on top of geometric setups. Goals address assigned parts and collect into a solver, where they are evaluated in an iterative simulation run. Every goal defines target states for geometries to converge towards. This is managed by addressing the fundamental unit that underlies most geometric constructions: points. The solver iteratively attempts to move those 'control points' towards their respective goals, while elastically morphing the origin geometry (line, polylines or mesh) in the process. Various goals can be layered on top of each other, whereby an individual point (within the larger system) might be affected by more than one goal at the same time. Points that are impacted by several goals with different objectives converge towards a balanced state. Even if not all participating goals might be resolved fully, the solution lies in releasing the highest amount of force that those goals introduce to the system.

\section{KIGUMI EXTENDED:}

Custom-programmed goals allow for intersecting lines to share interlacing points in a flexible matter. Those points can freely slide alongside all their corresponding line domains. Applying vertical pulling forces to all lines - while anchoring some points to the floor - results in an upside-down catenary geometry that emerges from the form generation (Fig. 6). During the iterative simulation process, the network continuously connects through its topology of all line chains and their flexible, hinge-like sliding intersection joints. After hundreds of iterations, all participating constraints (anchor, force, interlacing joint, line length) converge into a stable solution of an arching beam structure (Fig. 7). The form-finding process can be extended through additional der Struktur dient als Stützpunkt, an dem die Polylinien von innen nach außen, wachsen'. In Einzelschritten fügt der Algorithmus nacheinander Elemente hinzu, wobei dieser die neu erzeugte Diagonale kontinuierlich auf die Stelle mit der geringsten Steifigkeit ausrichtet. Wenn alle Polylinien den Rand des Gitters erreicht haben, stoppt der Algorithmus, und es entsteht ein einzigartiges, selbsttragendes räumliches Struktursystem.

\section{ZIELBASIERTES LÖSEN:}

Kangaroo2 dient als leistungsfähige Engine zur Formfindung, die verschiedene Constraints und physikalische Kräfte berücksichtigen kann. Diese kombinatorische Toolbox, die von Daniel Pirker entwickelt wurde, führt zielbasiertes Lösen auf der Grundlage geometrischer Setups durch. Ziele beziehen sich auf zugewiesene Bauteile und fließen in einen Solver ein, wo sie in einem iterativen Simulationslauf ausgewertet werden. Jedes Ziel definiert Sollzustände, denen sich die Geometrien annähern sollen. Dies geschieht durch die Adressierung einer grundlegenden Einheit, die den meisten geometrischen Konstruktionen zugrunde liegt, nämlich von Punkten. Der Solver versucht iterativ, diese ,Steuerungspunkte' in Richtung der jeweiligen Ziele zu bewegen und dabei die Ursprungsgeometrie (Linie, Polylinien oder Netz) elastisch zu verformen. Verschiedene Ziele können übereinandergeschichtet werden, wobei ein einzelner Punkt (innerhalb des größeren Systems) von mehr als einem Ziel gleichzeitig betroffen sein kann. Punkte, die von mehreren Zielen mit unterschiedlichen Zielsetzungen beeinflusst werden, konvergieren zu einem ausgeglichenen Zustand. Auch wenn nicht alle beteiligten Ziele vollständig aufgelöst werden können, liegt die Lösung in der Freigabe der höchsten Menge an Kraft, die diese Ziele in das System einbringen.

\section{KIGUMI EXTENDED:}

Individuell programmierte Ziele ermöglichen es, dass sich kreuzende Linien auf flexible Weise Verschneidungspunkte teilen. Diese Punkte können entlang aller zugehörigen Linienbereiche frei hin- und hergleiten. Durch die Anwendung von vertikalen Zugkräften auf alle Linien - bei gleichzeitiger Verankerung einiger Punkte am Boden - ergibt sich eine auf den Kopf gestellte Kettenliniengeometrie, die aus der Formgebung hervorgeht (Abb. 6). Während des iterativen Simulationsprozesses verbindet sich das Netzwerk kontinuierlich über seine Topologie aus allen Linienketten und deren flexiblen, scharnierartig gleitenden Kreuzungspunkten. Nach Hunderten von Iterationen fügen sich alle beteiligten Constraints (Anker, Kraft, Verschränkungsgelenk, Linienlänge) zu einer stabilen Lösung einer bogenförmigen 
constraints such as direction goals that further shape the collective body of lines.

\section{CONCLUSION:}

Top-down strategies such as 'hidden' control surfaces that operate as organizing instruments for beam sets, or bottom-up approaches like recursive L-system loops: the wide domain for creating modular beam structures is fundamentally defined by the relationship between part and whole. Managing this intricate relationship is what governs all atomic connections, as well as the collective sum. The immense amount of possibilities for combining simple lines to joint forms is developing with growing access to co-evolving computational algorithms. Digital building blocks can be remixed to advanced form simulators with various orchestrating effects. Feedback from real-time structural analysis is starting to influence beam choreographies in the same way geometric constraints or other coded instructions do. Tapping into those workflows hosts the potential to further investigate a territory between rigid modularity and an organic world of forces, and to probe new formal expressions in the process.

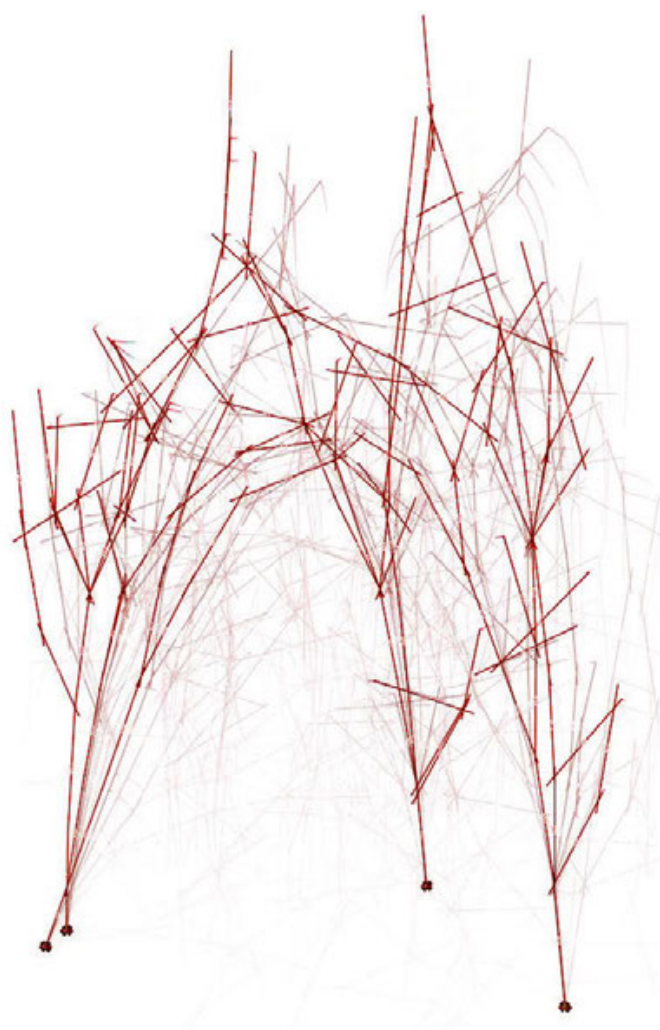

Stabkonstruktion zusammen (Abb. 7). Der Formfindungsprozess kann durch zusätzliche Constraints wie Richtungsziele erweitert werden, die den kollektiven Linienkörper weiter formen.

\section{FAZIT:}

Ob Top-down-Strategien wie, verdeckte` Steuerflächen, die als organisierende Instrumente für Stabgruppen fungieren, oder Bottom-up-Ansätze wie rekursive L-System-Schleifen: Der breite Ansatz zur Erstellung modularer Stabkonstuktionen wird grundsätzlich durch das Verhältnis zwischen dem Teil und dem Ganzem definiert. Die Handhabung dieser komplexen Beziehung bestimmt nicht nur sämtliche Verbindungspunkte, sondern auch die kollektive Summe. Die immense Menge an Möglichkeiten, einfache Linien zu gemeinsamen Formen zu kombinieren, entwickelt sich mit dem wachsenden Zugang zu gleichzeitig entstehenden Rechenalgorithmen. Digitale Bausteine können $\mathrm{zu}$ fortschrittlichen Formsimulatoren mit verschiedenen Orchestrierungseffekten neu gemischt werden. Feedback aus der Echtzeit-Strukturanalyse beginnt die Stabchoreografien auf die gleiche Weise zu beeinflussen wie geometrische Regeln oder andere codierte Instruktionen. Die Nutzung dieser Workflows birgt das Potenzial, das Territorium zwischen starrer Modularität und einer organischen Welt der Kräfte weiter zu erforschen und dabei neue formale Ausdrucksformen zu entdecken.
4Fig. 7|Abb. 7:

Animated geometry of interlaced beams, Kigumi Extended (image source: Adam Orlinski / Conceptual Joining research project University of Applied Arts Vienna). 